\title{
Pengelolaan Manajemen Pendidikan Di RA Al Mu'min, Kecamatan Medan Tembung, Kota Medan
}

\author{
Elya Siska Anggraini ${ }^{1,}$ Umma Mawaddah ${ }^{2}$ \\ ${ }^{1}$ Dosen PG PAUD FIP UNIMED \\ ${ }^{2}$ Mahasiswa PG PAUD FIP UNIMED \\ Jln. Williem Iskandar Pasar V Medan Estate, Medan, Sumatera Utara, 20371 \\ E-mail : elyasiskaanggraini@unimed.ac.id
}

\begin{abstract}
Abstrak: Pendidikan anak usia dini adalah pendidikan yang diberikan oleh orang dewasa kepada anak usia lahir sampai enam tahun untuk membantu anak masuk ke tahap pendidikan selanjutnya. Pendidikan Anak Usia Dini di beri wadah untuk mengembangkannya dalam bentuk lembaga PAUD. Saat berdirinya suatu lembaga PAUD tentunya harus dilakukannya manajemen pada lembaga tersebu mulai perencanaan, pengorganisasian, pelaksanaan, pengawasan dan penilaian agar program yang menjadi berdirinya suatu lembaga dapat berjalan dengan baik dan dapat tercapai sesuai dengan harapan dari lembaga tersebut. Penelitian ini bertujuan untuk mengetahui pengelolalan manajemen pendidikan pada lembaga PAUD RA AL Mu'min. Metode penelitian menggunakan metode penelitian kualitatif dengan pendekatan deskriptif. Sumber data pada penelitian ini adalah guru dan kepala sekolah sebagai narasumber. Pengumpulan data dilakukan menggunakan observasi. Hasil dari penelitian adalah pengelolaan manajemen pendidikan di RA Al Mu'min sudah berjalan dengan baik dan semestinya yang sesuai dengan Pasal 62 ayat 2, dan dapat merasakan sendiri fungsi dari pengelolaan manjemen tersebut.
\end{abstract}

Kata Kunci: : Pengelolaan, Manajemen Pendidikan, PAUD

\section{Pendahuluan}

Pendidikan anak usia dini adalah pendidikan yang diberikan oleh orang dewasa kepada anak usia lahir sampai enam tahun untuk membantu anak masuk ke tahap pendidikan selanjutnya. Menurut Peraturan Menteri Pendidikan dan Kebudayaan Republik Indonesia Nomor 146 Tahun 2014, pendidikan anak usia dini merupakan upaya pembinaan yang ditujukan pada anak sejak lahir sampai usia enam tahun yang dilakukan melalui pemberian rangsangan pendidikan untuk membantu pertumbuhan dan perkembangan jasmani dan rohani agar anak memiliki kesiapan dalam memasuki pendidikan lebih lanjut. Persyaratan umum pendirian lembaga PAUD adalah sejumlah ketentuan umum yang harus dipenuhi bagi sebuah Yayasan yang ingin mendirikan lembaga PAUD. Merujuk pada 2 Pasal 62 ayat 2, persyaratan yang harus dipenuhi untuk dapat menyelenggarakan lembaga pendidikan adalah Kurikulum, Peserta didik / Siswa / Anak Didik, Tenaga Kependidikan (Guru dan Staf), Sarana Prasarana, Pembiayaan Pendidikan dan Sistem Evaluasi. Saat 
berdirinya suatu lembaga PAUD tentunya harus dilakukannya manajemen pada lembaga tersebu mulai perencanaan, pengorganisasian, pelaksanaan, pengawasan dan penilaian agar program yang menjadi berdirinya suatu lembaga dapat berjalan dengan baik dan dapat tercapai sesuai dengan harapan dari lembaga tersebut.

Menurut kamus bahasa Indonesia, "Pengelolaan" memiliki akar kata "kelola", ditambah awalan "pe" an akhiran "an" yang artinya adalah ketatalaksanaan, tata pimpinan, pengelolaan. Manajemen atau pengelolaan adalah pengadministrasian, pengaturan atau penataan suatu kegiatan". Pengelolaan dapat diartikan semua kegiatan yang diselenggarakan oleh seseorang atau lebih dalam suatu kelompok atau organisasi/lembaga, untuk mencapai tujuan organisasi/lembaga yang telah ditetapkan. Pengelolaan adalah kemempuan atau keterampilan khusus untuk melakukan suatu kegiatan, baik bersama orang lain atau melalui orang lain dalam mencapai tujuan organisasi. Hersey dalam Sudjana (2000:17) mengemukakan: "Management as working with and through individuals and group to accoumplish organizational goals efficiently". Secara sederhana dapat dikatakan bahwa pengelolaan adalah proses kerja dengan dan melalui orang lain untuk mencapai tujuan organisasi secara efisien. Menurut Mulyasa (2005:20), manajemen atau pengelolaan merupakan komponen integral dan tidak dapat dipisahkan dari proses pendidikan secara keseluruhan. Alasannya, tanpa manajemen tidak mungkin tujuan pendidikan dapat diwujudkan secara optimal. Dalam hal inilah tumbuh kesadaran akan pentingnya manajemen dalam mengatur pendidikan dan pengajaran untuk membantu pelaksanaan pengajaran yang sesuai dengan tujuan pendidikan. Selanjutnya, Stoner dalam Sudjana (2000:17) mengemukakan bahwa: 'management is the process of planning, organizing, leading and controlling the efforts of organizing member and using all other organizational resources to achieve stated organizational goals'. Pada pernyataan diatas dapat disimpulkan bahwa fungsi pokok pengengelolaan yaitu 3 merencanakan, mengorganisasikan, memimpin, dan mengawasi. Keempat fungsi tersebut harus berjalan secara sinergis, agar tujuan dapat dicapai. Dalam pengelolaan pembelajaran, fungsi-fungsi tersebut dilakukan oleh seluruh unsur yang terlibat dalam proses pembelajaran. Manajemen penyelenggaraan berkaitan dengan tata laksana dan kelola lembaga, berkaitan dengan pengadministrasian, pengaturan, atau penataan kegiatan di lembaga. Manajemen berasal dari kata to manage yang berarti mengelola, memimpin atau mengarahkan. Manajemen sangat berperan penting dalam sebuah PAUD karena keberhasilan sebuah PAUD tidak lepas dari manajemen yang baik. Menurut Hapidin dkk (2012) Manajemen memiliki makna sebagai usaha mengelola, mengendalikan, dan mengarahkan berbagai sumber yang ada untuk mencapai tujuan yang diharapkan. 
Manajemen merupakan suatu proses mengkoordinasikan dan mengintegrasikan sumber daya melalui kegiatankegiatan agar diselesaikan secara efisien dan efektif dengan melibatkan orang lain. Pada dasarnya fungsi manajemen pada sebuah lembaga PAUD meliputi 4 fungsi dasaryang terkait satu dengan lainnya. Fungsi-fungsi manajemen tersebut meliputi:

1) Perencanaan, Mencakup menentukan visi misi, fungsi, mendefinisikan tujuan, menetapkan strategi, dan mengembangkan rencana untuk mengkoordinasikan kegiatan-kegiatan sebuah lembaga. Oleh sebab itu, seorang manajer sebelum menyelenggarakan pendidikan TK/PAUD sudah harus memikirkan visi dan misi lembaga yang akan didirikan, fungsi dari lembaga tersebut, tujuan mendirikan, strategi yang akan digunakan, rencana-rencana ke depan yang akan dilaksanakan. Kesemuanya merupakan suatu rangkaian dalam perencanaan lembaga pendidikan di lembaga PAUD.

2) Pengorganisasian, Meliputi penentuan tugas-tugas yang harus dikerjakan, pihak yang mengerjakan,tugas-tugas tersebut dikelompokkan dan dikelola, pihak yang melapor kepada siapa dan di tingkat mana keputusan-keputusan harus dibuat dan ditentukan

3) Kepemimpinan, Dalam memimpin sebuah lembaga TK/PAUD, seorang manajer harus bisa menciptakan kegiatan-kegiatan dengan cara memotivasi semua komponen sumber daya manusia yang terlibat dalam lembaga tersebut, mengarahkan kegiatankegiatan yang terbaik untuk meningkatkan lembaga tersebut, menyeleksi seluruh komunikasi agar tercipta secara efektif dan memecahkan konflik yang terjadi pada lembaga tersebut dengan cara yang arif dan bijaksana agar setiap keputusan yang diambil dapat diterima oleh semua komponen pendukung lembaga tersebut.

4) Pengawasan, Mencakup kegiatan-kegiatan pemantauan untuk memastikan bahwa semua komponen yang berada di bawah pengawasannya dapat berjalan dengan baik. Hal-hal yang dipantau meliputi tenaga struktural yaitu segala hal yang terkait dengan administrasi dan tenaga fungsional yaitu tenaga pendidik. Semua ini dilaksanakan agar dapat mencapai tujuan yang telah ditentukan sebelumnya sehingga apabila terjadi penyimpangan-penyimpangan dapat dengan cepat ditangani. Proses menajemen adalah kegiatan di mana organisasi membuat sumber daya manusiawi dan materi tersedia dan efektif untuk mencapai tujuan organisasi jadi suatu organisasi tidak mungkin bekerja dengan baik tanpa ada proses menajemen yang baik pula. Namun proses menajemen hanya mungkin berjalan dengan baik bila tersedia sumber manusiawi yang baik dan profesional dalam bidang-bidang tugas yang ada dalam organsasi. Dalam menjalankan sebuah 
lembaga pendidikan TK/PAUD hendaknya seorang manajer memperhatikan prinsip-prinsip manajemen pendidikan, hal ini dimaksudkan agar lembaga yang dikelolanya dapat menjadi lembaga yang tetap eksis sampai kapanpun. Prinsipprinsip yang dimaksud meliputi komitmen, profesionalitas, koordinasi (kesatuan kerja) serta Kepemimpinan

\section{Metode}

Metode penelitian yang digunakan dalam penelitian ini adalah penelitian kualitatif dengan pendekatan deskriptif yang bertujuan untuk menganalisis dan mendeskripsikan pengelolaan manajemen PAUD di RA Al Mu'min. Penelitian ini dilakukan di RA Al Mu'min yang beralamat di Jl. M. Saman Gg. Melati 7 No. 40B Bandar Khalipah, Kecamatan Medan Tembung. Subjek penelitian adalah kepala sekolah dan guru di RA Al Mu'min Penelitian ini dilakukan melakukan pengamatan secara lengsung dan melakukan wawancara dengan pihak sekolah RA Al Mu'min serta mengisi angket yang sudah disediakan oleh peneliti untuk mengetahui bagaimana manajemen pendidikan di RA Al Mu'min

\begin{tabular}{|c|c|c|}
\hline No & Langkah Manajemen & Tidak \\
\hline \multirow[t]{4}{*}{1} & Perencanaan : & \\
\hline & Visi Misi & \\
\hline & Program Kerja Tahunan Kepala Sekolah & \\
\hline & Rencana Kerja & \\
\hline \multirow[t]{4}{*}{2} & Pengorganisasian & \\
\hline & Struktur Organisasi & \\
\hline & Data pegawai dan tugas mengajar & \\
\hline & Tata tertib guru dan pegawai & \\
\hline \multirow[t]{7}{*}{3} & Pelaksanaan & \\
\hline & Terdapat kurikulum sekolah & \\
\hline & Adanya buku induk siswa & \\
\hline & Buku kas & \\
\hline & Buku tamu & \\
\hline & Penerimaan peserta didik baru & \\
\hline & Kwitansi pembayaran & \\
\hline \multirow[t]{3}{*}{4} & Pengawasan dan Penilaian & \\
\hline & Adanya instrumen kegiatan evaluasi dan penilaian & \\
\hline & Pelaporan kegiatan evaluasi dan penilaian & \\
\hline
\end{tabular}


Adakah penghargaan yang pernah diterima oleh sekolah

\section{Hasil dan Diskusi}

Kepekaan melihat kondisi global yang bergulir dan peluang masa depan menjadi modal utama untuk mengadakan perubahan paradigma dalam manajemen pendidikan. Modal ini akan dapat menjadi pijakan yang kuat untuk mengembangkan pendidikan. Pada titik inilah diperlukan berbagai komitmen untuk perbaikan kualitas. Ketika melihat peluang, dan peluang itu dijadikan modal, kemudian modal menjadi pijakan untuk mengembangkan pendidikan yang disertai komitmen yang tinggi, maka secara otomatis akan terjadi sebuah efek domino (positif) dalam pengelolaan organisasi, strategi, SDM, pendidikan dan pengajaran, biaya, serta marketing pendidikan. Untuk menuju point education change (perubahan pendidikan) secara menyeluruh, maka manajemen pendidikan adalah hal yang harus diprioritaskan untuk kelangsungan pendidikan sehingga menghasilkan out-put yang diinginkan. Walaupun masih terdapat institusi pendidikan yang belum memiliki manajemen yang bagus dalam pengelolaan pendidikannya. Manajemen yang digunakan masih konvensional, sehingga kurang bisa menjawab tantangan zaman dan terkesan tertinggal dari modernitas. Jika manajemen pendidikan sudah tertata dengan baik dan membumi, niscaya tidak akan lagi terdengar tentang pelayanan sekolah yang buruk, minimnya profesionalisme tenaga 6 pengajar, saranaprasarana tidak memadai, pungutan liar, hingga kekerasan dalam pendidikan. Manajemen dalam sebuah organisasi pada dasarnya dimaksudkan sebagai suatu proses (aktivitas) penentuan dan pencapaian tujuan organisasi melalui pelaksanaan empat fungsi dasar: planning, organizing, actuating, dan controlling dalam penggunaan sumberdaya organisasi. Karena itulah, aplikasi manajemen organisasi hakikatnya adalah juga amal perbuatan SDM organisasi yang bersangkutan

\begin{tabular}{llcl}
\hline No & \multicolumn{1}{c}{ Langkah Manajemen } & Ya & Tidak \\
\hline $\mathbf{1}$ & Perencanaan : & & \\
& Visi Misi & $\checkmark$ & \\
& Program Kerja Tahunan Kepala Sekolah & $\checkmark$ & \\
& Rencana Kerja & & \\
$\mathbf{2}$ & Pengorganisasian & $\checkmark$ & \\
& Struktur Organisasi & $\checkmark$ & \\
& Data pegawai dan tugas mengajar & $\checkmark$ & \\
& Tata tertib guru dan pegawai &
\end{tabular}




\begin{tabular}{ll}
\hline $3 \quad$ Pelaksanaan & \\
Terdapat kurikulum sekolah & $\checkmark$ \\
Adanya buku induk siswa & $\checkmark$ \\
Buku kas & $\checkmark$ \\
Buku tamu & $\checkmark$ \\
Penerimaan peserta didik baru & $\checkmark$ \\
Kwitansi pembayaran & $\checkmark$ \\
Pengawasan dan Penilaian & \\
Adanya instrumen kegiatan evaluasi dan penilaian & $\checkmark$ \\
Pelaporan kegiatan evaluasi dan penilaian & $\checkmark$ \\
Adakah penghargaan yang pernah diterima oleh & $\checkmark$ \\
sekolah &
\end{tabular}

Berdasarkan dari hasil penelitian maka dapat disampaikan bahwa: Pertama, Perencanaan.Dalam manajemen RA Al Mu'min perencanaan termasuk antara lain : visi misi sekolah,Dalam suatu lembaga tentunya harus melakukan perencanaan sekolah yan dimulai dari dibentuknya visi dan misi sekolah yang bertujuan untuk tercapainya 7 pencapaian standar ketntasann dan kelulusan pembelajaran dan terwujudnya anak yang peduli terhadap lingkungan dan memiliki akhlak mulia. Program kerja tahunan kepala sekolah, dalam proses perencanaan di RA Al Mu'min terdapat program rencana kerja tahunan kepala sekolah yang bertujuan untuk mempermudah menjalan tugas tiap tahunnya. Disusun dengan bentuk tabel ceklist dengan uraian tugas, adapun uraian tugas tersebut sebagai berikut: perencaan umum, prencanaan kurikulum, kesiswaan, personalia, gedung sarana/prasarana, keuangan. Rencana kerja RA Al Mu'min disusun mulai 20162020 yang isinya bagianbagian dari rencana kerja yaitu:fisik, peningkatan mutu guru, pemberdayaan orangtua, kerjasama instansi terkait, dan pemberdayaan yayasan. Kedua, Pengorganisasian dalam manajemen RA Al Mu'min. Pengorganisasian termasuk antara lain: Struktur organisasi RA Al Mu'min, Struktur organisasi RA Al Mu'min dapat dilihat untuk pelaksanaan tugas dari masing-masing struktur tersebut dari hasil wawancara kami dengan kepala sekolah berjalan sesuai dengan tugas masing-masing sesuai dengan strutur organisasi. Hanya saja dalam satu orang ada yang memegang dua jabatan/tugas. Seperti Sekretasis yang sekaligus menjadi guru dan operator sekolah sekaliguas menjadi seorang guru. Terlebih dari 2 jabatan dan memegang dua tugas tersebut pihak sekolah ataupun guru tidak mendapatkan kendala dari masing-masing tugasnya. Data pegawai dan tugas mengajar, Untuk pengorganisasian manajemen lembaga PAUD perlu adanya data pegawai dan tugas dari masing-masing orang agar bisa bertanggung jawab dalam 
melaksanakan tugasnya kedepan. Tata tertib guru dan pegawai, Saat melakukan pengorganisasian RA Al Mu'min melakukan pengorganisasian tata tertib guru dan pegawai agar mengetahui tata tertib dari masing-masing tugas yang dipegang oleh kepala sekolah, guru ataupun pegawai. Adapun tata tertib guru dan pegawai antara lain:jam kerja guru mulai pukul 07.00 WIB-11.00 WIB, semua guru harus hadir 15 menit sebelum kegiatan belajar dimulai, guru yang terlambat supaya memberitahukan kepada kepala RA Al Mu'min, guru yang tidak hadir karena sakit/hal yang lain harus memberitahukan secara tertulis kepada kepala RA Al Mu'min, tidak mengajar karena sakit lebih dari dua hari harus ada surat keterangan dari dokter, pukul 07.00 WIB semua guru harus sudah siap di kelas masingmasing, pada waktu kegiatan bermain bebas semua guru mengawasi dan mengevaluasi, pada waktu kegiatan belajar mengajar guru harus berupaya menggunakan alat bantu mengajar, pada akhir kegiatan belajar guru mengutamakan anak didiknya sampai ke pintu dan menyerahkan pada penjemputnya, bagi anak-anak yang terlambat dijemput agar dijaga 8 sampai penjemputnya datang, guru yang tidak bertugas/mengajar agar membantu guru yang sedang mengajar. Ketiga, Pelaksanaan.dalam manajemen RA Al Mu'min, pelaksanaan termasuk antara lain: kurikulum. Setiap lembaga PAUD diwajibkan untuk memiliki kurikulum. Adapun kurikulum yang digunakan dalam RA Al Mu'min yaitu kurikulum Raudhatul Athfal yang dirancang oleh Direktorat Pendidikan Madrasah, Direktorat Jenderal Pendidikan Islam Kementrian Agama Republik Indonesia pada tahun 2016. Terdapat buku induk siswa, dalam melaksanakan manajemen PAUD untuk pelasanaan tentunya harus terdapat buku induk siswa, tujuannya yaitu untuk memanajamen kesiswaan. Terdapat buku kas, dalam melaksanakan manajemen PAUD untuk pelaksanaan tentunya harus terdapat buku kas, tujuannya untuk memanajemen keuangan. Terdapat buku tamu, dalam melaksanakan manajemen PAUD untuk pelaksanaan tentunya harus terdapat buku tamu. Tujuannya untuk mendata tamu/kunjungan yang dilakukan oleh orangtua murid/wali murid ke PAUD. Terdapat penerimaan peserta didik baru, dalam melaksanakan penerimaan peserta didik baru di RA Al Mu'min melakukan cara dengan membagikan brosur kepada masyarakat yang berisi tempat pendaftaran dan syarat saat melakukan pendaftaran. Terdapat kwintasi pembayaran, dalam melaksanakan manajemen PAUD untuk pelaksanaan tentunya harus terdapat kwintasi pembayaran. Tujuannya untuk mendata pembayaran yang telah dilakukan oleh orangtua murid. Keempat, Pengawasan dan penilaian dalam manajemen RA Al Mu'min. Pengawasan dan penilaian termasuk antara lain: instrumen pengawasan proses dan hasil. Dalam melakukan pengawasan RA Al Mu'Min digunakan tabel supervisi guru dimana pada tabel tersebut terdapat kriteria, indikator dan penilaian yang dilakukan saat melakukan pengawasan dan penilaian tehadap kinerja guru, pelaporan, setelah kegiatan pengawasan proses dan hasil sudah 
selesai dilakukan, selanjutnya terdapat tahap pelaporan dimana RA Al Mu'min membuat lembar keterangan hasil supervisi evaluasi dari masing-masing guru. Adapun isi dari pelaporan ini adalah jenis SOP, hasil total angket dan rentang skor penghargaan, Terdapat penghargaan yang diterima oleh RA Al Mu'Min sebagai hasil dari tercapainya manajemen di RA Al Mu'min pada tingkat lokal dengan bukti adanya piala yang diraih oleh peserta didik dan RA Al Mu'Min.

\section{Kesimpulan}

Berdasarkan hasil penelitian yang telah dilakukan di RA Al Mu'min dapat disimpulkan bahwa pengelolaan manajemen di RA Al Mu'min sudah terkelola dengan baik.

1) Perencanaan pada RA Al Mu'min sudah termanajemen dengan baik mulai dari penentuan visi misi sekolah. Program rencana kerja tahunan kepala sekolah yang bertujuan untuk mempermudah menjalan tugas tiap tahunnya. Selanjutnya struktur organisasi RA Al Mu'min dapat dilihat untuk pelaksanaan tugas dari masing-masing struktur tersebut dari hasil wawancara peneliti dengan kepala sekolah berjalan sesuai dengan tugas masing-masing sesuai dengan strutur organisasi.

2) Dalam pelaksanaan manajemen kurikulum di RA Al Mu'min berdasarkan pada Direktorat Pendidikan Madrasah, Direktorat Jenderal Pendidikan Islam Kementrian Agama Republik Indonesia pada tahun 2016. Pelaksanaan manajemen di RA Al Mu'min juga dilengkapi dengan adanya buku kas, buku induk siswa, dan buku tamu. Seluruh pengelolaan manajemen di RA Al Mu'min juga tidak terlepas dari pengawasan dan pengevaluasian agar seluruh perencanaan yang telah direncanakan berjalan sesuai dan mampu mencapai tujuan dengan baik.

\section{Daftar Rujukan}

Hapidin . Modul 1 Konsep Dasar Manajemen Pendirian Lembaga TK/PAUD.

Imron, Ali. 2004. Manajeman Peserta Didik Berbasis Sekolah. Malang. Universitas Negeri Malang

Suryana, Dadan.2019. Manajemen Pendidikan Anak Usia Dini Berbasi Akreditasi Lembaga.Jakarta : Prenada Media Group.

Suharni . 2019 . Manajemen Pendidikan Anak Usia Dini Pada Paud Bintang Rabbani. Pekanbaru.Volume 4 No 1. Halaman 1-5.

Mulyasa, 2012. Manajemen PAUD. Bandung: Remaja Rosdakarya.

Mukminin, Amirul. 2011. Manajemen Penyelenggaraan Pendidikan Anak Usia Dini. Semarang: UNNES. Diakses pada Juni 2021 
Rohmat . 2017. Manajemen Pendidikan anak usia dini. Jurnal Yin Yang . Volume 12 No 2. Hal 300-325. Diakses pada Juni 2021

Mariah . 2019. Pentingnya manajemen dalam pengelolaan pendidikan. Hal 535-536. Diakses pada Juni 2021

Hapidin. 2012. Manajemen Pendidikan TK/PAUD. Universitas Terbuka : Tangerang Selatan.

Rifa'i, dkk. 2013. Manajemen Organisasi, Bandung: Citapustaka Media Perintis,

Usman, dan Husaini, Manajemen Teori, Praktik Dan Riset Pendidikan Edisi 3, Jakarta: Bumi Aksara, 2011 